\title{
Alternative Cyanide- and Antimycin A-insensitive Respiratory System in Sporobolomyces Red Yeasts
}

\author{
Atsushi SHIRAISHI and Hisao FuJII \\ Faculty of Home Life Science, Fukuoka Women's University, \\ Kasumigaoka, Fukuoka 813, Japan
}

Received July 24, 1985

\begin{abstract}
Sporobolomyces ruberrimus is insensitive to antimycin A which is a respiratory inhibitor of the cytochrome system, as cyanide is. When this red yeast was cultured in the presence of antimycin A, the growth curve showed the same pattern as that of the normal culture in the absence of it, but the growth mass was only about $70 \%$ of that of the normal culture. The antimycin A-insensitive and cyanide-insensitive respiration of $S p$. ruberrimus was inhibited by pyrocatechol and salicylhydroxamic acid. Sporobolomyces red yeasts have two characteristic terminal oxidase systems; one is a cytochrome oxidase system and the other is a cyanide- and antimycin A-insensitive oxidase system. The proportions of the two respiratory systems differed among the species and strains of Sporobolomyces red yeasts examined.
\end{abstract}

The functions of alternative cyanideinsensitive respiratory systems have already been discussed, and a scheme was proposed for the fungus, Neurospora crassa. ${ }^{1)}$ As previously reported, ${ }^{2)}$ a similar respiratory system is present in Sp. ruberrimus, that is not inhibited by cyanide or carbon monoxide. This yeast cyanide-insensitive respiratory pathway was inhibited by $o$-diphenol derivatives and salicylhydroxamic acid (SHAM).

In this paper, we report that cyanideinsensitive respiration is widespread among Sporobolomyces red yeasts. Furthermore, we describe the effect of antimycin $\mathrm{A}$ on the cyanide $(\mathrm{CN})$-sensitive and -insensitive respirations.

\section{MATERIALS AND METHODS}

Microorganisms. Sporobolomyces ruberrimus ${ }^{3)}$ and other red yeast strains stocked in our laboratory were used in this experiment.

Oxygen uptake. Oxygen uptake was measured by the Warburg manometric technique at $25^{\circ} \mathrm{C}$. The results obtained were expressed as $\mathrm{Q}_{\mathrm{O}_{2}}$ values. The values given in this paper are the ratios to control $\mathrm{Q}_{\mathrm{O}_{2}}$ values for autorespiration and glucose oxidation.
Medium. The strains used were cultured in the medium at $25^{\circ} \mathrm{C}$ for 2 days and rested as described previously. ${ }^{4)}$

Reagents. Antimycin A (Sigma Chemical Co.) was dissolved in absolute ethanol $(\mathrm{mg} / \mathrm{ml})$ and diluted with distilled water when used.

Cultures in the presence of antimycin $A .1 \mu \mathrm{g}$ or $10 \mu \mathrm{g}$ of antimycin A per $\mathrm{ml}$ (final concentration) was added to the medium as described previously. ${ }^{4}$ Sp. ruberrimus was inoculated into $50 \mathrm{ml}$ of the medium with antimycin $\mathrm{A}$ in a $500 \mathrm{ml}$ shaking flask and incubated a $25^{\circ} \mathrm{C}$ with reciprocal shaking. The weight of the growing cells of $S p$. ruberrimus was determined at $12 \mathrm{hr}$ intervals.

AM-cells. Sp. ruberrimus cells were incubated in the above medium containing $1 \mu \mathrm{g}$ of antimycin A per ml (final concentration) at $25^{\circ} \mathrm{C}$ for $48 \mathrm{hr}$ with shaking and then rested in $0.2 \mathrm{M}$ phosphate buffer ( $\mathrm{pH} 5.8$ ) containing $1 \mu \mathrm{g}$ of antimycin A per $\mathrm{ml}$ for another $24-\mathrm{hr}$ at $25^{\circ} \mathrm{C}$ with shaking. The cells thus prepared were called AM-cells.

Other experimental methods were the same as described previously. ${ }^{2)}$

\section{RESULTS}

Antimycin A is known as a respiratory inhibitor of cytochrome systems, as cyanide is. $S p$. ruberrimus was investigated as to whether it exhibited insensitive respiration in the presence of antimycin $\mathrm{A}$, as in the presence of 


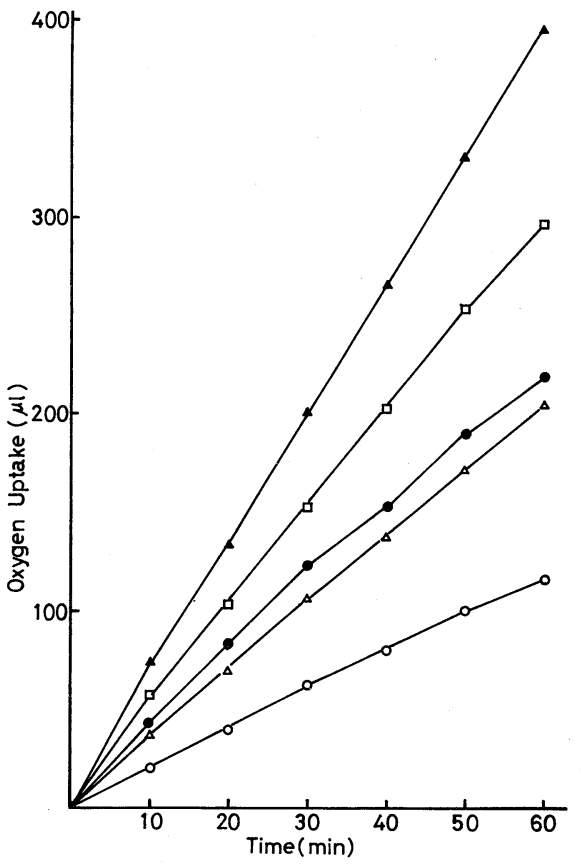

FIG. 1. Effect of Antimycin A on Respiration of Sporobolomyces ruberrimus.

When antimycin A was used, it was dissolved in a very small volume of ethanol $(1 \mathrm{mg} / \mathrm{ml})$ and diluted with distilled water $(\mu \mathrm{g} / \mathrm{ml})$. Each manometer vessel contained $1 \mathrm{ml}$ of a cell suspension in $0.2 \mathrm{M}$ phosphate buffer $(\mathrm{pH} 5.8)$, reagent(s) and distilled water to bring the volume to $2.0 \mathrm{ml}$, and $0.3 \mathrm{ml}$ of $10 \%$ of $\mathrm{KOH}$ was placed in the center well. The total volume was $2.3 \mathrm{ml}$. $\bigcirc-\mathrm{O}$, no addition; $\triangle-\triangle, 0.2 \mathrm{ml}$ of $1 \%$ ethanol; -, $0.5 \mathrm{ml}$ of $4 \%$ glucose; $\square-\square, 0.2 \mathrm{ml}$ of $10 \mu \mathrm{g} / \mathrm{ml}$ antimycin $\mathrm{A} ; \boldsymbol{\Delta}-\boldsymbol{\Lambda}$, $0.2 \mathrm{ml}$ of $10 \mu \mathrm{g} / \mathrm{ml}$ antimycin $\mathrm{A}$ and $0.5 \mathrm{ml}$ of $4 \%$ glucose.

cyanide, or not. As shown in Fig. 1, the respiration of $S p$. ruberrimus was not inhibited at all, but, in fact, it was moderately accelerated by antimycin A, exactly as in the case of cyanide. But this antimycin A (AM)insensitive respiration was almost completely inhibited by the addition of pyrocatechol, as in the case of $\mathrm{CN}$-insensitive respiration (Fig. 2). Therefore, the alternative respiratory system of $S p$. ruberrimus was suggested to be as shown in Fig. 3, which Lambowitz et al. ${ }^{5)}$ proposed for the poky mutant mitochondria of the $N$. crassa respiratory system.

Whether or not this AM-insensitive respiratory system is physiologically active in $S p$. ruberrimus was examined. $S p$. ruberrimus was

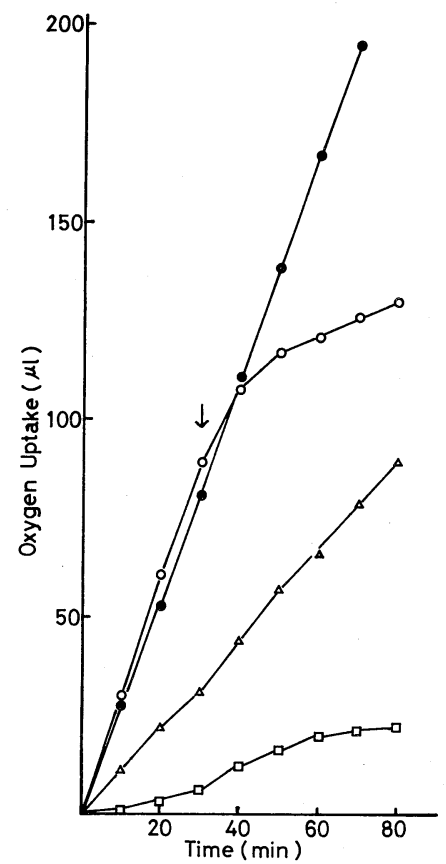

FIG. 2. Effects of Antimycin A and/or Pyrocatechol on Autorespiration of Sporobolomyces ruberrimus.

The conditions were the same as in Fig. 1. $\triangle-\triangle$, no addition; - $1 \mu \mathrm{g} / \mathrm{ml}$ antimycin $\mathrm{A} ; \bigcirc-\bigcirc, 1 \mu \mathrm{g} / \mathrm{ml}$ antimycin $\mathrm{A}$ and, after $30 \mathrm{~min}, 10 \mathrm{~mm}$ pyrocatechol was added; $\square-\square, \quad 1 \mu \mathrm{g} / \mathrm{ml}$ antimycin $\mathrm{A}$ and $10 \mathrm{~mm}$ pyrocatechol.

The arrow indicates the time of addition of pyrocatechol.

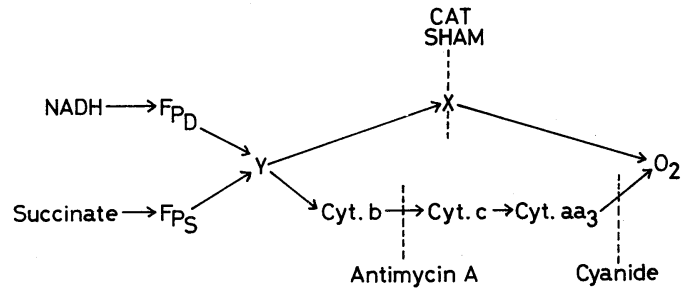

FIG. 3. Branched Electron Transport System.

$Y$ denotes the branch point and $X$ denotes the cyanideand antimycin A-insensitive oxidase system, according to Lambowitz et al. ${ }^{5)}$ The sites of inhibition by inhibitors are indicated by dashed lines.

SHAM, salicylhydroxamic acid; CAT, pyrocatechol.

inoculated into a liquid medium containing $5 \%$ sucrose, $0.5 \%$ peptone, $0.1 \% \mathrm{KH}_{2} \mathrm{PO}_{4}$, $0.1 \% \mathrm{NaNO}_{3}, 0.05 \% \mathrm{MgSO}_{4} \cdot 7 \mathrm{H}_{2} \mathrm{O}$ and $1 \mu \mathrm{g}$ or $10 \mu \mathrm{g}$ of antimycin A per $\mathrm{ml}(\mathrm{pH} 5.8)$, cultivated at $25^{\circ} \mathrm{C}$ with shaking and then sampled at $12 \mathrm{hr}$ intervals to determine the cell 




FIG. 4. Effect of Antimycin A on the Growth of Sporobolomyces ruberrimus.

Sporobolomyces ruberrimus was grown in a liquid medium containing $5.0 \%$ sucrose, $0.5 \%$ peptone, $0.1 \%$ $\mathrm{KH}_{2} \mathrm{PO}_{4}, 0.1 \% \mathrm{NaNO}_{3}, 0.05 \% \mathrm{MgSO}_{4} \cdot 7 \mathrm{H}_{2} \mathrm{O}$ and antimycin $\mathrm{A}$ at $25^{\circ} \mathrm{C}$ with shaking.

$\mathrm{O}-\mathrm{O}$, control; $\triangle-\triangle, 1 \mu \mathrm{g}$ of antimycin A per ml;

- $10 \mu \mathrm{g}$ of antimycin A per ml; $\square-\square, 1 \mu \mathrm{g}$ of antimycin A and $0.2 \mathrm{mg}$ of SHAM per $\mathrm{ml}$.

Refer to Fig. 1 for other conditions.

weight (Fig. 4). Sp. ruberrimus grew in the presence of $1 \mu \mathrm{g}$ or $10 \mu \mathrm{g}$ antimycin $\mathrm{A}$, although the cell weights were less than in the absence of antimycin A, and the growth curve with antimycin A showed a striking resemblance to the normal growth curve. The coexistence of antimycin A and SHAM, which did not effect the respiration of this yeast individually, strongly inhibited the growth of the yeast. Consequently, it is possible that this insensitive respiratory system is physiologically active in $S p$. ruberrimus but with an inferior efficiency as to glucose oxidation, different from in the case of the normal respiratory system.

As previously reported, ${ }^{2,4)}$ on carbohydrate utilization this red yeast oxidizes $3 \mathrm{M}$ of $6 \mathrm{M}$ glucose and assimilates the other $3 \mathrm{M}$ in the presence of cyanide. The glucose utilization of AM-cells, which were cultured in the presence of antimycin A, was compared with that of normal cells in the presence of cyanide. As shown in Fig. 5, the efficiency of glucose oxidation in the former cells is the same as that in the latter cells with cyanide but is somewhat inferior to that in normal cells.

Also, the AM-insensitive respiration in AMcells was inhibited by SHAM, as well as pyrocatechol.

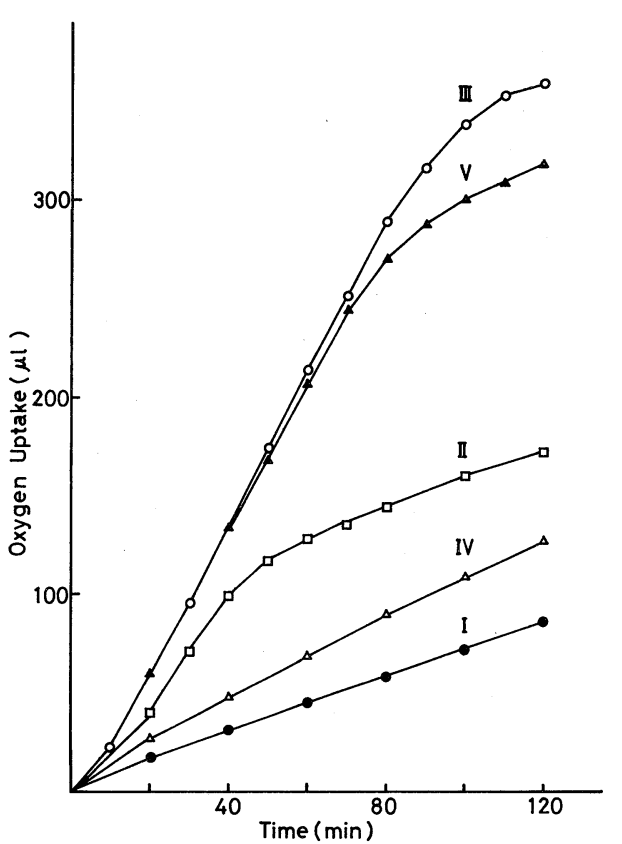

FIG. 5. Balance of Glucose Consumption and Oxygen Uptake in Normal Cells and AM-Cells.

Sporobolomyces ruberrimus was grown in $100 \mathrm{ml}$ of the medium used in Fig. 4, containing $1 \mathrm{ml}$ of $100 \mu \mathrm{g}$ of antimycin $\mathrm{A}$ per $\mathrm{ml}$ in $10 \%$ ethanol, at $25^{\circ} \mathrm{C}$ for 2 days with shaking. The cells were harvested by centrifugation and then washed three times with $0.9 \%$ saline. They were resuspended in $0.2 \mathrm{M}$ phosphate buffer ( $\mathrm{pH} 5.8$ ) with $1 \mu \mathrm{g}$ of antimycin A per $\mathrm{ml}$ in $0.1 \%$ ethanol and shaken for another 24 -hr at $25^{\circ} \mathrm{C}$. The cells thus obtained were called AM-cells. The other conditions were the same as in Fig. 1 except that $1 \mathrm{ml}$ of the cell suspension was placed in a side arm. Normal cells: I, no addition; II, $5 \mu \mathrm{M}$ glucose; III, $5 \mu \mathrm{M}$ glucose and $2 \mathrm{~mm} \mathrm{NaCN}$, AM-cells: IV, no addition; $\mathrm{V}, 5 \mu \mathrm{M}$ glucose. 
Table I. Effect of NaCN on the Respiration of Various Sporobolomyces Species and Strains

\begin{tabular}{|c|c|c|c|c|}
\hline \multirow{2}{*}{ Strain } & \multicolumn{2}{|c|}{$\begin{array}{l}\text { Autorespiration } \\
2 \mathrm{~mm} \mathrm{NaCN}\end{array}$} & \multicolumn{2}{|c|}{$\begin{array}{l}\text { Glucose oxidation } \\
2 \mathrm{~mm} \mathrm{NaCN}\end{array}$} \\
\hline & $\overline{\mathrm{Q}_{\mathrm{O}_{2}}}$ & $\begin{array}{c}+ \\
\text { Ratio }\end{array}$ & $\overline{\mathrm{Q}_{\mathrm{O}_{2}}}$ & $\begin{array}{c}+ \\
\text { Ratio }\end{array}$ \\
\hline $\begin{array}{l}\text { Sporobolomyces alborubescens } \\
\text { IFO } 1031\end{array}$ & 5.98 & 130 & 29.07 & 51 \\
\hline Sp. odorus IFO 1035 & 2.71 & 163 & 26.66 & 25 \\
\hline Sp. odorus IFO 1606 & 3.27 & 216 & 16.32 & 125 \\
\hline Sp. roseus* & 4.35 & 213 & 33.65 & 82 \\
\hline Sp. roseus IFO 1105 & 6.01 & 167 & 31.29 & 44 \\
\hline Sp. pollacii IFO 1037 & 9.94 & 156 & 23.87 & 100 \\
\hline Sp. tenuis IFO 1040 & 6.39 & 219 & 18.46 & 107 \\
\hline Sp. holsaticus IFO 1034 & 3.27 & 171 & 9.52 & 116 \\
\hline Sp. holsaticus IFO 1032 & 5.71 & 233 & 31.92 & 72 \\
\hline Sp. pararoseus IFO 1103 & 8.94 & 89 & 24.24 & 33 \\
\hline Sp. pararoseus IFO 0376 & 9.33 & 209 & 39.96 & 52 \\
\hline Sp. pararoseus IFO 1104 & 8.54 & 209 & 16.08 & 104 \\
\hline Sp. pararoseus IFO 1107 & 8.17 & 170 & 44.56 & 106 \\
\hline Sp. salmonicolor* & 6.67 & 20 & 22.21 & 8 \\
\hline Sp. salmonicolor IFO 0375 & 5.70 & 16 & 27.21 & 5 \\
\hline Sp. ruberrimus* & 7.00 & 227 & 16.02 & 147 \\
\hline Sp. ruberrimus var. albus* & 7.45 & 187 & 10.61 & 201 \\
\hline
\end{tabular}

$$
\text { Ratio }=\frac{\mathrm{Q}_{\mathrm{O}_{2}} \text { with } \mathrm{NaCN}}{\mathrm{Q}_{\mathrm{O}_{2}} \text { without } \mathrm{NaCN}} \times 100 . \quad * \text {, Refer to ref. 3. }
$$

Other Sporobolomyces yeasts. Then, Sporobolomyces red yeasts other than $S p$. ruberrimus were investigated as to the alternative respiratory system. As shown in Table I, the oxygen uptake of various red yeast strains with and without cyanide was expressed as $\mathbf{Q}_{\mathrm{O}_{2}}$ values for autorespiration and glucose oxidation. As to autorespiration, the Sporobolomyces red yeasts tested showed increasing respiration as in the case of $S p$. ruberrimus, except for $S p$. pararoseus and $S p$. salmonicolor. The rate of the accelerated oxygen uptake differed according to the species and strains tested. Consequently, it is possible that these Sporobolomyces red yeasts have two respiratory systems, that is, one is a normal cytochrome oxidase system and the other is an alternative respiratory system.

As to glucose oxidation, Sp. holsaticus IFO 1032, Sp. alborubescens, $S p$. pararoseus IFO 0376, Sp. roseus and Sp. roseus IFO 1105 showed slightly inhibited respiration, different from in the case of the accerelated oxygen uptake on autorespiration. Sp. odorus, $S p$. pararoseus, Sp. salmonicolor and $S p$. salmonicolor IFO 0375 showed remarkable inhibition.

The effects of cyanide, antimycin A, pyrocatechol and SHAM on the respiration of Sporobolomyces red yeasts were investigated too. The results are presented in Table II. The values shown in the Table are the ratios to the $\mathrm{Q}_{\mathrm{O}_{2}}$ values without reagent for autorespiration and glucose oxidation. The respiration of the Sporobolomyces red yeasts tested was accelerated by antimycin A, smilar to in the case of cyanide, for autorespiration and glucose oxidation, but that of Sp. salmonicolor IFO 0375 was considerably inhibited in both cases. When the tests were performed in the presence of $\mathrm{NaCN}$ or antimycin $\mathrm{A}$ and pyrocatechol or SHAM, the results differed with the species or strains tested.

As to autorespiration, $S p$. holsaticus IFO 1032 and Sp. odorus IFO 1606 did not show complete inhibition on the addition of $\mathrm{NaCN}$ and SHAM or pyrocatechol. As to glucose 
Table II(a). EfFects of Inhibitors on Autorespiration of Sporobolomyces Species and Strains

\begin{tabular}{|c|c|c|c|c|c|c|c|c|c|c|c|}
\hline & Auto & $\mathrm{CN}$ & $\mathrm{AM}$ & SHAM & CAT & $\begin{array}{c}\text { CN } \\
+ \\
\text { SHAM }\end{array}$ & $\begin{array}{c}\mathrm{CN} \\
+ \\
\mathrm{CAT}\end{array}$ & $\begin{array}{c}\text { AM } \\
+ \\
\text { SHAM }\end{array}$ & $\begin{array}{c}\mathrm{AM} \\
+ \\
\mathrm{CAT}\end{array}$ & $\begin{array}{c}\mathrm{AM} \\
+ \\
\mathrm{CN}\end{array}$ & $\begin{array}{c}\text { SHAM } \\
+ \\
\text { CAT }\end{array}$ \\
\hline Sp. ruberrimus & $\begin{array}{c}100 \\
(5.96)\end{array}$ & 237 & 251 & 123 & 148 & 23 & 0 & 33 & 25 & 259 & 126 \\
\hline $\begin{array}{r}\text { Sp. pararoseus } \\
\text { IFO } 0376\end{array}$ & $\begin{array}{c}100 \\
(9.33)\end{array}$ & 209 & 200 & 143 & 194 & 17 & 20 & 13 & 12 & 213 & 266 \\
\hline $\begin{array}{r}\text { Sp. pararoseus } \\
\text { IFO } 1107\end{array}$ & $\begin{array}{c}100 \\
(8.17)\end{array}$ & 170 & 364 & 164 & 191 & 6 & 26 & 7 & 9 & 195 & 155 \\
\hline $\begin{array}{r}\text { Sp. pararoseus } \\
\text { IFO } 1104\end{array}$ & $\begin{array}{c}100 \\
(8.54)\end{array}$ & 209 & 421 & 127 & 132 & 10 & 4 & 9 & 0 & 393 & 162 \\
\hline $\begin{array}{l}\text { Sp. holsaticus } \\
\text { IFO } 1032\end{array}$ & $\begin{array}{c}100 \\
(5.71)\end{array}$ & 233 & 320 & 186 & 540 & 71 & 66 & 83 & 64 & 101 & 314 \\
\hline $\begin{array}{c}\text { Sp. salmonicolor } \\
\text { IFO } 0375\end{array}$ & $\begin{array}{c}100 \\
(5.70)\end{array}$ & 16 & 24 & 126 & 573 & 20 & 28 & 48 & 57 & 13 & 211 \\
\hline $\begin{array}{l}\text { Sp. roseus } \\
\text { IFO } 1105\end{array}$ & $\begin{array}{c}100 \\
(6.01)\end{array}$ & 167 & 271 & 114 & 309 & 11 & 8 & 26 & 18 & 211 & 188 \\
\hline $\begin{array}{l}\text { Sp. odorus } \\
\text { IFO } 1606\end{array}$ & $\begin{array}{c}100 \\
(3.27)\end{array}$ & 216 & 910 & 246 & 469 & 92 & 82 & 196 & 202 & 831 & 702 \\
\hline
\end{tabular}

All values are ratios to the values for autorespiration.

The values in parentheses are the $\mathrm{Q}_{\mathrm{O}_{2}}$ values for autorespiration.

Table II(b). Effects of Inhibitors on Glucose Oxidation of Sporobolomyces Species and Strains

\begin{tabular}{|c|c|c|c|c|c|c|c|c|c|c|c|}
\hline & Glucose & $\mathrm{CN}$ & $\mathrm{AM}$ & SHAM & CAT & $\begin{array}{c}\text { CN } \\
+ \\
\text { SHAM }\end{array}$ & $\begin{array}{c}\mathrm{CN} \\
+ \\
\mathrm{CAT}\end{array}$ & $\begin{array}{c}\text { AM } \\
+ \\
\text { SHAM }\end{array}$ & $\begin{array}{c}\mathrm{AM} \\
+ \\
\mathrm{CAT}\end{array}$ & $\begin{array}{c}\mathrm{AM} \\
+ \\
\mathrm{CN}\end{array}$ & $\begin{array}{c}\text { SHAM } \\
+ \\
\text { CAT }\end{array}$ \\
\hline Sp. ruberrimus & $\begin{array}{c}100 \\
(20.25)\end{array}$ & 149 & 191 & 115 & 103 & 14 & 13 & 28 & 9 & 164 & 108 \\
\hline $\begin{array}{r}\text { Sp. pararoseus } \\
\text { IFO } 0376\end{array}$ & $\begin{array}{c}100 \\
(39.96)\end{array}$ & 52 & 91 & 99 & 96 & 5 & 3 & 6 & 4 & 83 & 109 \\
\hline $\begin{array}{r}\text { Sp. pararoseus } \\
\text { IFO } 1107\end{array}$ & $\begin{array}{c}100 \\
(44.56)\end{array}$ & 106 & 159 & 99 & 83 & 20 & 2 & 78 & 4 & 47 & 18 \\
\hline $\begin{array}{r}\text { Sp. pararoseus } \\
\text { IFO } 1104\end{array}$ & $\begin{array}{c}100 \\
(48.08)\end{array}$ & 104 & 141 & 106 & 92 & 5 & 3 & 6 & 6 & 117 & 93 \\
\hline $\begin{array}{l}\text { Sp. holsaticus } \\
\text { IFO } 1032\end{array}$ & $\begin{array}{c}100 \\
(31.92)\end{array}$ & 72 & 65 & 103 & 121 & 37 & 12 & 12 & 6 & 58 & 118 \\
\hline $\begin{array}{c}\text { Sp. salmonicolor } \\
\text { IFO } 0375\end{array}$ & $\begin{array}{c}100 \\
(27.21)\end{array}$ & 5 & 18 & 111 & 140 & 5 & 8 & 18 & 24 & 4 & 123 \\
\hline $\begin{array}{l}\text { Sp. roseus } \\
\quad \text { IFO } 1105\end{array}$ & $\begin{array}{c}100 \\
(31.29)\end{array}$ & 44 & 41 & 99 & 99 & 11 & 11 & 9 & 5 & 20 & 92 \\
\hline $\begin{array}{l}\text { Sp. odorus } \\
\text { IFO } 1606\end{array}$ & $\begin{array}{c}100 \\
(16.32)\end{array}$ & 125 & 141 & 172 & 202 & 15 & 9 & 39 & 40 & 90 & 207 \\
\hline
\end{tabular}

All values are ratios to the values for glucose oxidation.

The values in parentheses are the $\mathrm{Q}_{\mathrm{O}_{2}}$ values for glucose oxidation.

oxidation, all strains tested were not affected by pyrocatechol or SHAM but were inhibited when they coexisted with $\mathrm{NaCN}$ or antimycin A.

From the results described above, it can be assumed that Sporobolomyces red yeasts have two respiratory systems, a cytochrome oxidase system and a $\mathrm{CN}$ - and AM-insensitive respiratory system, and the proportions of these two respiratory systems in Sporobolomyces 
differ with the species or strains.

\section{DISCUSSION}

The respiration of $S p$. ruberrimus was insensitive to antimycin $\mathrm{A}$ as well as cyanide. Also, the AM-insensitive respiration was inhibited by pyrocatechol and SHAM, as the $\mathrm{CN}$-insensitive respiration was. That this AMinsensitive respiration physiologically occurs in Sp. ruberrimus was confirmed by the results of the growing culture test with antimycin A. Since the growth mass in the presence of antimycin A was less than that of normal cells, the efficiency of the alternative respiratory system as to glucose oxidation is very inferior compared to the cytochrome oxidase system (Fig. 4).

Also, as to the glucose that disappeared in AM-cells, $3 \mathrm{~m}$ of $6 \mathrm{~m}$ glucose was oxidized and the other $3 \mathrm{~m}$ was assimilated as in the case of $\mathrm{CN}$-insensitive respiration. The utilization of glucose by AM-cells is very inferior compared to that of normal cells (Fig. 5).

All Sporobolomyces strains tested, except
Sp. salmonicolor, have both $\mathrm{CN}$ - and AMinsensitive respiration and a cytochrome oxidase system like $S p$. ruberrimus. It may be assumed that the proportions of the two respiratory systems differ according to the species or strains, respectively.

The insensitive respiratory chains in cell free system will be reported elsewhere. This problem still requires further investigation.

Acknowledgments. The authors thank Misses Y. Fujita, Y. Takamatsu, K. Ohtaguro and Y. Kumagai for their technical assistance.

\section{REFERENCES}

1) H. Degn, D. Lloyd and A. C. Hill, "Function of Alternative Terminal Oxidases," Pergamon Press, 1978.

2) A. Shiraishi and H. Fujii, Agric. Biol. Chem., 50, 441 (1986).

3) I. Yamasaki and H. Fujii, Nippon Nôgeikagaku Kaishi, 24, 11 (1950).

4) I. Yamasaki, H. Fujii, I. Yamamoto and T. Ide, Bull. Agric. Chem. Soc. Jpn., 21, 340 (1957).

5) A. M. Lambowitz, C. W. Slayman, C. L. Slayman and W. D. Bonner, J. Biol. Chem., 247, 1536 (1972). 